\title{
Fertility and Legal Abortions
}

\author{
By MARKETTA RITAMIES
}

The Population Research Institute

The rise in abortions brought about by a more liberal abortion law has been one of the factors mentioned when discussing the causes for the low level of fertility in Finland today. In this article the development of fertility and abortions in Finland will be examined and an attempt will be made to estimate the effect of the liberalization of the abortion law on fertility.

\section{The development of fertility and abortions}

The first law concerning abortions took force in Finland in 1950. According to this Act an abortion could be performed for medical reasons, and in addition: for medico-social and ethical reasons. This abortion Act was in force for two decades. In 1970 it was expanded to include social reason as a basis for abortion In the summer of 1979 the Act was amended so that an abortion done for social reasons must be performed during the first 12 weeks of pregnancy instead of the first 16 weeks as previously.

The trend of the crude birth rate which depicts the development of fertility has been declining from the beginning of the 1950 s to the year 1973 when fertility was at its lowest. At this point only 12.2 children were born per 1000 inhabitants (Figure 1). Fertility then began to rise, but recently it has begun to decline again slightly. In 1978 the crude birth rate was 13.5 per thousand.

During this same period the development of legal abortions has taken the opposite direction. Since 1950 the proportion of legal abortions has grown except for a decline in the mid-1960s. Most legal abortions were performed in 1973, 22.4 abortions per 1000 females aged 15-44. After that abortions have been less frequent. In 1978 the corresponding figure was 16.6.

The decline in fertility began in the $1950 \mathrm{~s}$ in the older age groups and gradually moved to the younger ones. In 1961-72 fertility was highest in the $20-24$-year-old age group. In the last few years the average age of women giving birth has begun to climb again and since 1973 fertility has been highest among the 25-29-year-olds.

In the 1960 s the $20-24$-year-olds were the largest age group having abortions, although quite a large number of abortions were performed on women over 30 . On the other hand, abortions among women under 20 were relatively rare. By 1977 abortion patients were getting younger. The $20-24-$ 
Figure 1. Live births per 1000 inhabitants and legal abortions per 1000 women aged $15-44$ in $1950-78$.

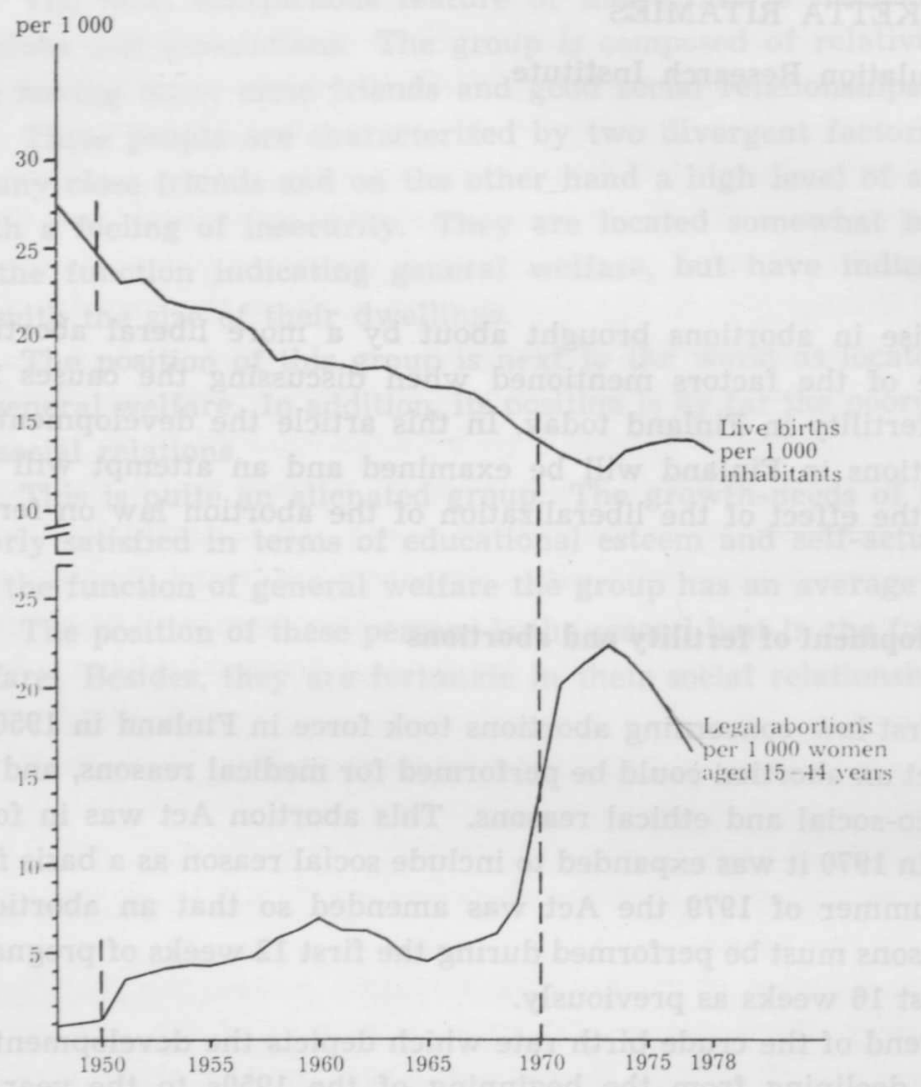

year-olds continued to make up the largest age group, but an increasing number of abortions were being performed among the 15-19-year-olds. The proportion of patients in the older age groups has started to decline (Figure 2).

The marital status of women giving birth and of abortion patients has also changed in the $1970 \mathrm{~s}$. The proportion of unmarried women among abortion patients has increased. In 1969, which represents the period before the new Abortion Act, they made up over $30 \%$ of all abortion patients, but by 1978 , their share was over $50 \%$ (Table 1 ). However, a real risk group is formed by the widowed and divorced. The largest relative increase occurred in their group. (Rasimus 1979.)

In Finland women giving birth have usually been married. The proportion of unmarried women among those giving birth has varied between 4 and $5 \%$. One might have expected the increase in the proportion of unmarried women among abortion patients to cause a decrease in illegitimate births, but this is not so. On the contrary, the proportion of illegitimate births in the 1970 s has continued to grow. In 1973 the proportion of illegitimate births was $8 \%$ and 
Fig ure 2. Legal abortions by age of female in 1969, 1973 and 1977.

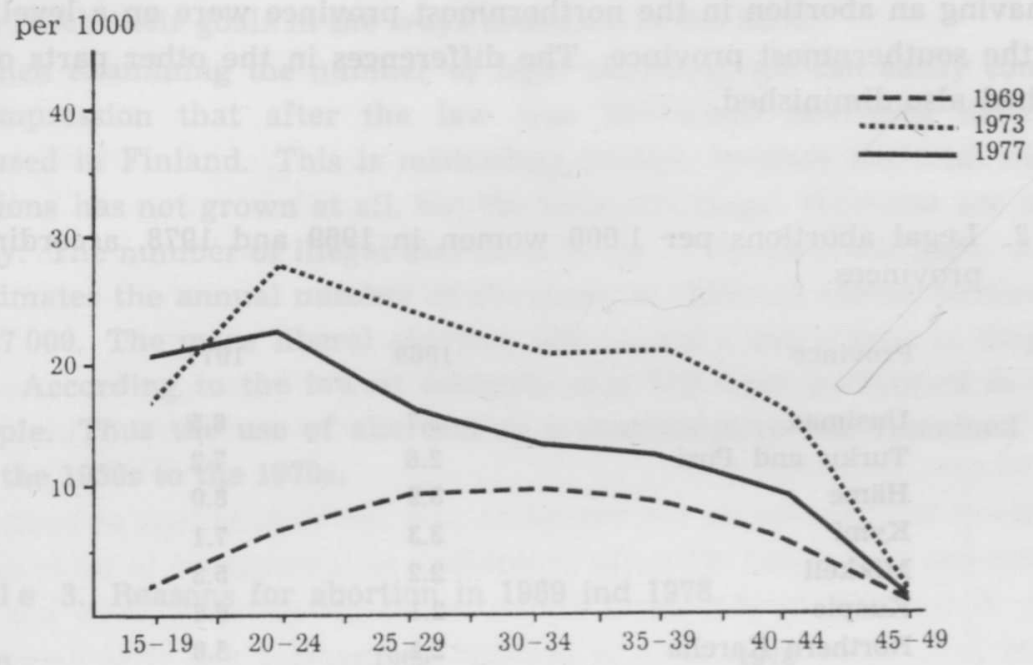

in 1978 it already $11 \%$. Apparently the rise is due to the increase in consensual unions. It is estimated that in 1978 in Finland $5 \%$ of the population aged 15 and over was living in a consensual union.

Before the free abortion law came into force the fewest abortions were performed in the eastern and northern parts of the country, where the standard of living and the state of health of the population was the lowest. It was hoped that the change in the law would alter the situation and make it equally possible for women in all parts of the country to have an abortion. Whether this has been reached can be seen in Table 2. It shows the legal abortions made in each province in 1969 before the current law, and the present situation in 1977, after the effects of the law have stabilized.

In the 1970 s the number of abortions is now more evenly distributed regionally. In 1969 the country's southernmost province, Uusimaa, where Helsinki is situated, was in a special position compared to the rest of the nation. A definitely larger number of abortions were performed there than in the rest of the

Table 1. Legal abortions according to marital status in 1969 and 1978.

$\begin{array}{lrr}\text { Marital status } & 1969 & 1978 \\ & & \\ \text { Unmarried } & 33.3 & 53.3 \\ \text { Married } & 59.5 & 35.3 \\ \text { Other } & 7.2 & 11.4 \\ \text { Total } & 100.0 & 100.0\end{array}$

* Other $=$ widowed, divorced, separated

Source: Lääkintöhallituksen moniste

Suomen virallinen tilasto XI 72,73 , Oikeuslääketieteelliset toimenpiteet 
country. In 1977 the situation had definitely improved because the opportunities for having an abortion in the northernmost province were on a level with those in the southernmost province. The differences in the other parts of the country had also diminished.

$\mathrm{Table} 2$. Legal abortions per 1000 women in 1969 and 1978 , according to provinces.

$\begin{array}{lll}\text { Province } & 1969 & 1977 \\ \text { Uusimaa } & 5.7 & 8.5 \\ \text { Turku and Pori } & 2.6 & 7.2 \\ \text { Häme } & 3.9 & 8.0 \\ \text { Kymi } & 3.3 & 7.1 \\ \text { Mikkeli } & 2.2 & 5.3 \\ \text { Kuopio } & 2.1 & 6.6 \\ \text { Northern Karelia } & 2.1 & 5.8 \\ \text { Vaasa } & 1.9 & 5.8 \\ \text { Central Finland } & 2.7 & 6.4 \\ \text { Oulu } & 2.0 & 6.2 \\ \text { Lapland } & 2.6 & 8.3 \\ \text { Entire country } & 3.4 & 7.3\end{array}$

Source: Sukupuolikasvatustyöryhmän mietintö, liite 13

A significant change has taken place in the reasons for performing an abortion since the Abortion Act of 1970 came into force (Table 3). Before $197060 \%$ of all abortions were performed for a basic medical reason and $36 \%$ for a medical reason which included some social aspects. The most frequent diagnosis was neurosis, overexhaustion or weakness. In 1978 abortions performed for social reasons comprised $77 \%$ of all abortions. Medical reasons totalled only $4 \%$. The abortion request usually failed to specify the type of social reason; however, $55 \%$ of abortions performed for social reasons were given to unmarried women.

\section{Abortions and fertility}

When considering the relation between the free abortion law and the changes in fertility one must remember that the growth in the number of legal abortions is only of secondary importance in determining the development of fertility. The development of fertility cannot be influenced purely by abortion legislation and information on contraception, instead the decisive factors are the goals and motives people have about having or not having children. If the abortion law is made more liberal or more rigid, it may, for a moment, affect 
the number of abortions. Gradually, however, people adapt to the changes and try to reach their goals in the ways available at the time.

When examining the number of legal abortions one can easily come under the impression that after the law was liberalized abortions have greatly increased in Finland. This is misleading though, because the total number of abortions has not grown at all, but the formally illegal abortions are now done legally. The number of illegal abortions in the $1950 \mathrm{~s}-60 \mathrm{~s}$ was high. According to estimates the annual number of abortions in 1958-66 varied between 18000 and 27000 . The more liberal abortion law caused a sharp drop in illegal abortions. According to the lowest estimate only 200 were performed in 1974, for example. Thus the use of abortion as a contraceptive has remained constant from the 1950 s to the 1970 s.

$\mathrm{Table} 3$. Reasons for abortion in 1969 ind 1978.

$\begin{array}{lrr}\text { Reason } & 1969 & 1978 \\ \text { Medical } & 59.9 & 4.3 \\ \text { Social } & 35.7 & 77.3 \\ \text { Age (under 17 or over 40) } & 1.9 & 14.5 \\ \text { More than 4 children } & - & 3.0 \\ \text { Other reasons * } & 2.5 & 0.9 \\ \text { Total } & 100.0 & 100.0\end{array}$

* Other reasons: ethical, eugenic, person unable to care for child or emergency Source: Sukupuolikasvatustyöryhmänmietintö, liite 6, Lääkintöhallituksen moniste

The effect of the 1970 Abortion Act on fertility has been shown quite convincingly by Lahti $(1973: 28,308)$ to have been non-existent. When estimating the number of pregnancies that would have ended in birth under the old abortion law, it was found that the number of births had declined much less than the number of abortions would have indicated. The new Abortion Act thus did not decrease fertility.

The small family ideal has been generally accepted in Finland. There are now an average of 1.6 children per family. According to research data gathered in 1971 representing the entire country (Sievers et al. 1974) the average number of children among 45-54-year-old married women who had attained their final family size was 3.0. According to interview data from 1977 (World Fertility Survey) 40-44-year-old women at their first marriage who had passed their fertile period had given birth to an average of 2.7 children. Differences in the number of children in various population groups are evening out, although some difference remain, for example, between educational and occupational groups.

It is possible that the use of contraceptives in Finland has decreased after the new Abortion Act and that abortion is being used as a means of birth control instead of other methods of contraception? A comparison of the results 
of the two fertility studies mentioned above shows that in the 1970 s knowledge about contraceptive methods has continued to improve in Finland. In 1977 only $0.2 \%$ of 18 -44-year-old married women were not able to mention a single method of contraception.

The use of contraceptive methods has also improved in the $1970 \mathrm{~s}$ in that fewer women resort to unreliable methods. The condom continues to be the most common method of contraception, but the IUD has become an almost equally accepted form of control in the 1970s. The pill, however, has decreased in popularity. In Finland people very rarely use the unreliable method of withdrawal anymore, while in 1971 it was still the third-most common method in use. Among those interviewed only $2 \%$ said they had used it in 1977 as a means of contraception.

In Finland information on contraception and the distribution of contraceptive devices has never been officially prohibited, as it continues to be in certain countries. Since 1972 birth control aimed at all groups of citizens has been decreed by law. Here the aim is to prevent pregnancies and it is hoped that people will resort to abortion only when contraception has failed. Birth control information is given free-of-charge at health centers. In addition, information on contraceptives is dispensed by private physicians and private clinics.

$\mathrm{T}$ a ble 4. Present contraceptive practice of married women aged $18-44$ in 1971 and 1977.

$\begin{array}{lrr}\begin{array}{l}\text { Contraceptive } \\ \text { method used }\end{array} & 1971 & 1977 \\ \text { Pill } & 20 & 11 \\ \text { IUD } & 3 & 27 \\ \text { Condom } & 30 & 30 \\ \text { Withdrawal } & 15 & 2 \\ \text { Rhythm } & 1 & 1 \\ \text { Women's methods } & 3 & 1 \\ \text { No risk } & 25 & 21 \\ \text { No contraception } & 3 & 8 \\ \text { Total } & 100 & 100\end{array}$

Source: World Fertility Survey, Ennakkotiedot

At first glance, it seems that people have begun to resort to abortion as a means of contraception somewhat more frequently now than in the years right after the Abortion Act came into force. Abortions performed in 1970-71 were the first ones for $96 \%$ of the women, the second for $3.5 \%$ and the third for $0.1 \%$. According to preliminary data for 1978 first-time abortion patients now made up only $80 \%$, this was the second abortion for $17 \%$ and for three per cent this was the third or more. It is clear that right after the liberalization 
Fig u re 3. Legal abortions and unemployment in 1970-1977.

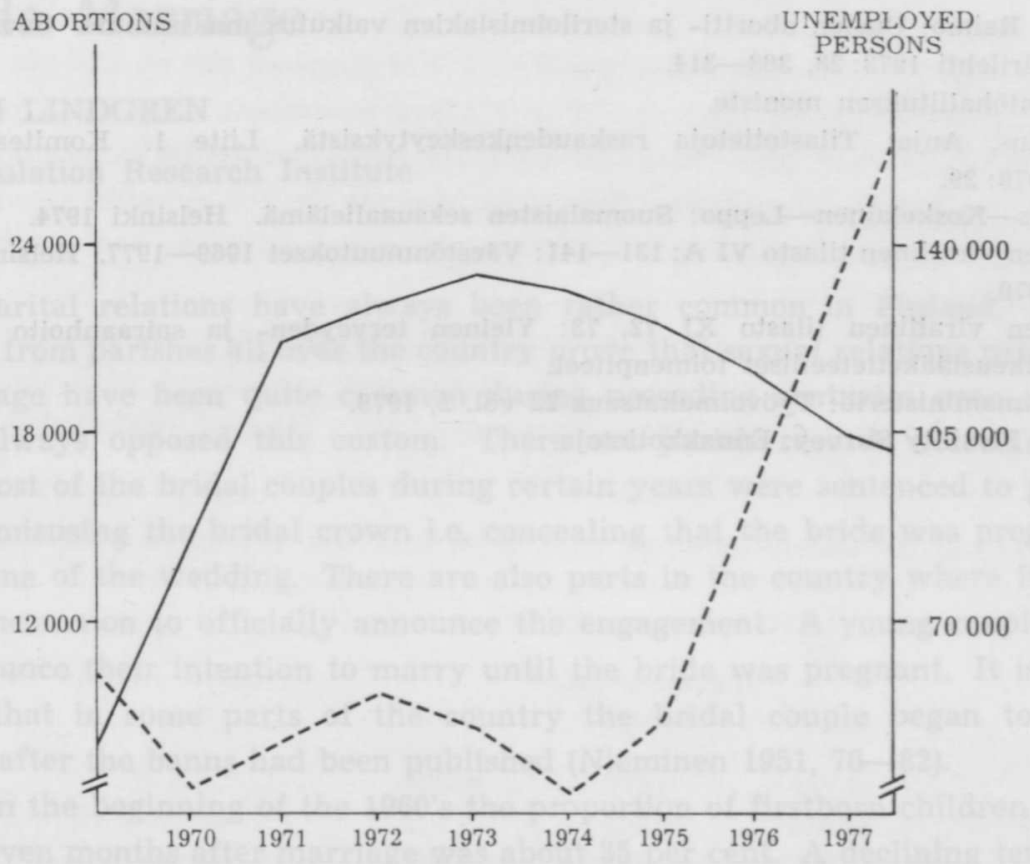

of the law abortion patients were usually first-timers and only gradually did the proportion of women grow for whom this was a second or more abortion. An examination of the development in the amount of abortions among 15-49year-olds shows that the proportion having an abortion for the first time has decreased by one-third since 1973 , but the proportion having two or more abortions has remained almost unchanged.

A correspondence has been found between the growth in abortions and economic well-being. When economic development is on the decline people consider carefully whether or not to have children and try to be more careful than usual in the use of birth control.

If the growth of the unemployed is considered a sign of a decline in economic development, Figure 3 should show that abortions have decreased in the last few years. And so they have in Finland. Unemployment has increased strongly at the end of the 1970 s and at the same time the number of abortions has also declined. The change in the abortion law caused an exceptional rise in abortions at the beginning of the decade, thus making it difficult to make a comparison with the size of the unemployed.

However, it is not possible to discern the causal relationships between fertility and abortions purely on the basis of statistics. A broad and manysided analysis is needed. 


\section{References}

Lahti, Raimo: Uusien abortti- ja steriloimislakien vaikutus maassamme. Suomen Lääkärilehti 1973: 28, 303-314.

Lääkintöhallituksen moniste.

Rasimus, Anja: Tilastotietoja raskaudenkeskeytyksistä. Liite 1. Komiteanmietintö 1979: 29.

Sievers-Koskelainen-Leppo: Suomalaisten seksuaalielämä. Helsinki 1974.

Suomen virallinen tilasto VI A: 131-141: Väestönmuutokset 1969-1977. Helsinki 19721979.

Suomen virallinen tilasto XI 72, 73: Yleinen terveyden- ja sairaanhoito 1969-70: Oikeuslääketieteelliset toimenpiteet.

Työvoimaministeriö: Työvoimakatsaus 22 vol. 2, 1979.

World Fertility Survey: Ennakkotietoja. 